\title{
Non-financial reporting in the public sector: alternatives, trends and opportunities
}

\author{
Vicente Montesinos ${ }^{\mathrm{a}}$, Isabel Brusca ${ }^{b}$ \\ a) University of Valencia, Spain \\ b) University of Zaragoza, Spain
}

${ }^{b}$ Corresponding author.

E-mail address: ibrusca@unizar.es

\section{A R T I C L E I N F O}

\section{Article history:}

Received 08 Jun 2018

Accepted 17 Jun 2018

Available online 1 July 2019

\section{JEL classification:}

G34

L32

M14

M48

O38

Keywords:

Integrated Reporting

Non-financial reporting

Non-financial rep
Popular reporting

Sustainability reporting

\section{A B S T R A C T}

In recent years, different non-financial information models have arisen, both in the private and public sectors, trying to complete the traditional financial reports prepared by companies and public administrations. The fundamental objective of these models has been to satisfy the interest of the stakeholders, which goes beyond the numbers included in the balance sheet and the income statement. In the case of the public sector, this is coupled with the discontent and distrust of citizens towards politicians and administrators of institutions, which makes it necessary to emphasize tools and strategies that can improve the transparency and accountability of administrations and restore citizen trust. Therefore, this article highlights the differ ent non-financial information alternatives that have emerged in the literature, their practical application in the public sector and the opportunities that these models offer for the future. Specifically, we refer to sustainability reporting, integrated reporting, the non-financial report recently regulated for the business sector and, finally, popular reporting.

C2019 ASEPUC. Published by EDITUM - Universidad de Murcia. This is an open access article under the CC BY-NC-ND license (http://creativecommons.org/licenses/by-nc-nd/4.0/).

La información no financiera en el sector público: alternativas, tendencias y oportunidades

\section{R E S U M E N}

En los últimos años han irrumpido con fuerza distintos modelos de información no financiera, tanto en el sector privado como en el público, tratando de completar el tradicional informe financiero preparado por empresas y administraciones públicas. El objetivo fundamental de estos modelos ha sido satisfacer el interés del conjunto amplio de los stakeholders, que va más allá de los números recogidos en el balance de situación y la cuenta de resultados. En el caso del sector público, a esto se une el descontento generalizado y la desconfianza de los ciudadanos hacia los políticos y administradores de las instituciones, lo que hace necesario poner el acento en todas aquellas herramientas y estrategias que puedan perfeccionar la transparencia y responsabilidad de las administraciones y reintegrar la confianza de sus administrados. Por ello, en este artículo se ponen de relieve las distintas alternativas de información no financiera que han ido surgiendo en la literatura, su aplicación práctica en el ámbito del sector público y las oportunidades que estos modelos ofrecen para el futuro. En concreto nos referimos a la información sostenible, la información integrada, la información popular y por último, al informe no financiero regulado en nuestra normativa para el sector empresarial.

(C)2019 ASEPUC. Publicado por EDITUM - Universidad de Murcia. Este es un artículo Open Access bajo la licencia CC BY-NC-ND (http://creativecommons.org/licenses/by-nc-nd/4.0/) 


\section{Introduction}

The information contained in the traditional annual reports, mainly of a financial nature, has proved insufficient to meet the needs of the different interest groups, and reports on social responsibility, corporate governance and sustainability have emerged as a fundamental complement to financial reporting. These reports are a useful tool for accountability from a perspective that exceeds the strictly financial frame, covering areas such as social or environmental. This information has become more relevant with the financial crisis, climate change and other events that have highlighted the importance of contributing to society not only in economic but also social and environmental terms, thus trying to address the scandals that have taken place in some companies. This has involved the publication of scattered information in different reports that are sometimes difficult to understand or compare.

In recent years, a trend has emerged that proposes the integration of different types of information in the same report, thus giving rise to the concept of integrated information. Some authors consider that it reflects a paradigm shift or that it could even be the end of accounting (Lev and Gu, 2016). In 2013 the International Council for Integrated Information (IIRC) published the conceptual framework of integrated information, which aims to define the fundamental concepts and serve as a guide for the implementation of integrated reporting in practice.

In the public sector, the insufficiency of financial information is recognized even in conceptual pronouncements (Governmental Accounting Standards Board, 1994; International Public Sector Accounting Board-IPSASB, 2014), recommending the preparation of performance reporting and indicators as a complement to traditional financial statements. It seems therefore that the concepts and philosophy of these information models could be appropriate for public sector entities, which now more than ever need to provide information to citizens and put in place transparency mechanisms to recover the trust of citizens and legitimize their governments. In short, the integrated report can reinforce the objective of informative transparency, highlighting the capacity of the entities as agents generating economic value and wealth for society as a whole. However, there are few entities in the non-business public sector that have had an initiative to implement an integrated report. This may be a future challenge for public administrations, both in the national and international context.

This short paper aims to analyse, first, the sustainability reports, highlighting their origin and the development they have had in practice. Second, the conceptual framework of integrated information prepared by the IIRC is analysed, as well as the extent to which this framework can be applied to public sector entities and the adaptations that may be necessary. Third, given the recent introduction of the nonfinancial information statement in the business sector, this article refers to its application in the field of public administrations. Fourth, the paper makes a short analysis of the elaboration of popular reports, in which the non-financial report, the sustainability and integrated reporting could be introduced. For each of these alternatives, the practical application and the possibilities they can offer for accountability to citizens are discussed.

The paper is structured as follows: after this introduction, in section 2 we refer to the convenience and future challenges that non-financial information may imply for public sector. After that, we have the sections devoted to sustainable and in- tegrated reporting, the non-financial statement and the popular report. The work finishes with a summary of the main conclusions.

\section{The relevance of non-financial information in the public sector}

Management systems of public administrations have been subject to a continuous debate in recent years, accentuated by recent corruption scandals that have occurred at an international level. This situation requires that administrations make improvements in transparency to comply with the objectives of efficient management and accountability, with positive benefits to gain legitimacy. Citizens have lost trust in their governments and the latter need to increase their reliability. These circumstances show that public administrations can benefit from any initiative with accountability objectives, among which would be the preparation and dissemination of non-financial information.

Non-financial information has been considered an integral part of the annual reports of public administrations since the first initiatives for the standardization of annual reports. In 1994, the US accounting standardization body, the Governmental Accounting Standards Board (GASB), issued a pronouncement that included the need to complete the financial information of public administrations with non-financial information, which would allow to inform of service efforts and accomplishments (GASB, 1994). This information, usually collected in the Anglo-Saxon concept of "performance reporting" or "performance indicators" has received great interest, both in regulation and in the literature and most of accounting standards boards have recognized that it should be part of the annual reports. For example, the Recommended Practice Guide No. 3 of the International Public Sector Accounting Standards Board (IPSASB, 2015), in which public administrations are recommended to include information on their performance in terms of economy, efficiency and effectiveness in their annual report. In Spain, the General Public Sector Accounting Plan also requires public administrations, and in particular all local governments with more than 50,000 inhabitants, to publish indicators of economy, efficiency and efficiency in the provision of services, in the notes to the financial statements. These indicators are therefore part of the non-financial information.

In this article, however, we want to expand the concept of non-financial information to include social, environmental and governance aspects, which are traditionally included in the idea of non-financial information in the business sector (Flores et al., 2012). Public administrations provide services without direct compensation and financed through taxes, and their main objective is to seek the social welfare of their citizens, in all areas, for which they must have active policies that allow them to fulfil their obligations to provide services responsibly, including social and environmental aspects. In addition, they must communicate the results of these processes to their stakeholders, and demonstrate the sustainable value of the services provided. Traditional information has also been revealed as insufficient in this regard (IPSASB, 2015), because the objectives of the administrations go beyond the strictly financial. Therefore, non-financial information can become a future challenge for public administrations (Katsikas et al., 2016).

The fulfilment of this requirement to provide non-financial information can be achieved through different tools and strategies, which have also evolved over time. For many years now, the pioneers of these initiatives in the business 
sector have proposed the preparation of social responsibility reports and sustainability reports, whose objective is to complete the information contained in the financial report with social and environmental aspects. A recent evolution of these concepts towards integrated information, which has generated great interest from institutions and researchers, has led to the proposal to integrate both financial and non-financial information in an integrated report. In Spain, the regulation has established the obligation to publish non-financial information for some companies, reflected in a statement of non-financial reporting. This paper therefore reviews these alternatives and their practical application in the field of public administrations. We also refer to the popular report because of the interest it is receiving in some countries for the disclosure of financial and non-financial information for specific stakeholders such as citizens.

It is worth mentioning that information technologies also allow important advances in the dissemination of information and communication with stakeholders and the internet has emerged as a useful tool. Currently, most administrations disclose social and environmental information on their websites, but this option is not specifically addressed in the paper because the objective is to study the preparation of nonfinancial reports and not only the disclosure of information.

\section{Social responsibility and sustainability reports in the public sector}

The concept of Social Responsibility arose in the business sector in the 1950s, but it has been gaining relevance since the 1990s, especially with the globalization and internationalization of companies and some environmental scandals. The important thing is that the company should create value for all the groups affected by its activity and not only for shareholders and investors. The social responsibility/sustainability reports, were born as an accountability instrument of this responsibility of the company to the interest groups, the social and environmental aspects acquiring special relevance in this way.

In order to promote and even standardize these sustainability reports, the Global Reporting Initiative (GRI) was created in 1997. Since then, it has issued different guidelines and recommendations for the elaboration of sustainable reports. At present, the G4 Guide for the preparation of sustainability reports (GRI, 2013) is being used by many companies to prepare their sustainability report and has become a useful tool to achieve the comparability of sustainable information. In 2018, the Global Sustainability Standards Board (GSSB) was created to issue GRI Standards.

The objectives and scope of these sustainability reports are fully applicable in the field of public administrations and, in fact, the GRI itself in 2005 published a pilot version of the G1 Guide for Public Agencies with the aim of analyzing specific aspects of the sector. Subsequent guidelines have no longer included specific applications for the public sector, understanding that its pronouncements were fully applicable to non-profit and public entities, as stated in a study carried out by the GRI Commission in Australia.

However, several studies confirm that the preparation of sustainability reports has not been widespread in the public administrative sector, with the exception of some countries. The GRI (2010) conducted a study to see the degree of implementation of reports in government agencies and concluded "sustainable information is still in its infancy in the public sector (only $1.7 \%$ of reports published in GRI in 2009 are public entities". Australia and New Zealand are the countries in which these reports have received the greatest acceptance. At present, 13,323 entities have deposited their sustainability reports in the GRI database, of which 244 correspond to public entities $(1.8 \%)$. In addition, most of them are public business entities. Only 25 correspond to local administrations, distributed by regions as shown in Table 1 .

Table 1

Sustainability reports of local entities in GRI

\begin{tabular}{lc}
\hline Region & Total number \\
\hline Europe & 7 \\
Oceania & 8 \\
North America & 8 \\
Latin America & 1 \\
Asia & 1 \\
Total & 25 \\
\hline
\end{tabular}

Source: GRI database (2019)

However, it should be mentioned that public universities have not been included in the group of public agencies, because they have their own category. In total, 152 universities have published their reports in the GRI database, some of which are public. In particular, 13 Spanish universities have deposited a sustainability report, of which 6 are public. However, only the University of Cadiz publishes its sustainability report in a regular and continuous way in the GRI database. They are followed by the universities of Cantabria and the International de Andalucia, which although they have not published it annually, keep that strategy alive.

In the case of local entities, of the 7 European entities that have published their sustainability report, one of them corresponds to a Spanish local government, the City of Valencia, which registered its 2009 report. However, the fact that the government has not maintained the elaboration of the report periodically can indicate that it was a sporadic impulse motivated by the fashion of the moment or by the involvement of certain responsible officers of the area. In a web search, we have only found the reports of the municipalities of Huesca (2015) and Torrent (2015-2016). On the other hand, in the Valencian Community, a network of Valencian municipalities for sustainability was created in 2001 and there were several municipalities that launched initiatives for the preparation of sustainability reports.

It can be said therefore that in Spain the preparation of sustainability reports has not penetrated in the field of public administrations. In fact, this is evident in the work carried out by Navarro et al., (2010) for the 55 largest local entities, where the authors note that these entities do not disclose formally Reports on Corporate Social Responsibility (CSR), although all of them disseminate in their web pages certain information that, together with their CSR commitments, reaches $40 \%$ of the total items defined according to the GRI proposals. Similarly, the work of Abellán Giménez et al., (2017), focused exclusively on 4 municipalities of the Murcia region, confirms that social and environmental indicators are not disclosed by these local administrations.

Finally, it is relevant to say that the Order ESS/1554/2016, of September 29, regulates the procedure for the registration and publication of the reports of social responsibility and sustainability of companies, organizations and public administrations in Spain. So far, only 129 entities have deposited their reports. The only administration that has deposited its report is the Government of La Rioja for 2018, although its 
contents do not respond to the standards set out in the GRI or in the academic literature, nor to the recommendations of the regulation itself.

\section{Integrated reporting}

Integrated reporting emerged in business sector with the aim of adopting a holistic approach for the companies, focused on the process of creating value within the firms. This initiative aims to integrate financial, sustainable and corporate governance reporting. Eccles et al., (2012) highlight that integrated information allows stakeholders to be involved in the strategic management of the company, while improving the quality of information and the company's position in sustainability.

The main objective of an integrated report, according to the IIRC (2013), is to explain to investors and other stakeholders how an organization creates value over time. The main argument is that the current reports offer a partial and disconnected view of the results obtained by the companies, without any vision of the interconnections between risks, opportunities and strategies. In fact, there is talk of a new era for information (Flores et al., 2012), although integrated reporting is voluntary in most countries. It can be highlighted the exception of South Africa, where it is compulsory for public and private companies listed on the stock exchange, becoming leader in the application of integrated reporting. The IIRC considers that integrated information should be, more than just an information system, an integrated approach to thinking, with changes in the form of governance and in the strategic management of the organization. The more internalized the integrated approach is in the organization, the easier it will be to prepare the integrated report and the better its quality.

The IIRC has elaborated the conceptual framework of integrated reporting (IIRC, 2013), with the aim of achieving its comparability and standardization, establishing a series of fundamental concepts and basic principles that must be followed for the effective implementation of integrated information (Adams, 2013). This conceptual framework has been developed considering the context of the companies and it can be used by companies of any size, but the IIRC itself indicates that it can also be applied, with the adaptations that are necessary, to non-profit entities and those in the public sector.

Subsequently, the Chartered Institute of Public Finance and Accountancy (CIPFA) of the United Kingdom, together with the IIRC (2016), published a guide for the application of integrated reporting in the public sector, in which the following advantages are highlighted for integrated information in the public sector:

a) Increase accountability to stakeholders and groups of interest. Integrated reports can help entities to meet accountability requirements. An integrated report provides information on the nature and quality of the organization's relationships with its main stakeholders, including information regarding how adequate the services provided are for the needs and interests of its citizens. An integrated report is intended to benefit all parties interested in the creation of value in the organization, including employees, recipients of services, suppliers, regulators, managers and politicians.

b) Serve as a guide for the provision of sustainable services, given that the integrated report provides a strategic vision of the organization, showing the use of resources and their interrelation with the results obtained from a broad perspective, which includes the social and environmental perspective. c) Allow the adoption of a long-term orientation in management, since they must communicate not only the results of their actions now, but also the future impact that they may have. For example, integrated reporting should report the activities of the organization to create value in the short, medium and long term. This will include the creation of value for the interested groups, with special attention to the citizens.

In short, this new orientation intends to create "a holistic approach to decision making, which focuses on the creation of value in the short, medium and long term; definition of more robust and integrated objectives and strategies; consideration of the risks and opportunities of the organization in the decision-making process; better understanding of the process of providing services and identifying possible gaps in the process; greater connection of internal and external communication " (CIPFA, 2016, P. 20).

These benefits and advantages show that this approach to information could be very useful for public administrations. The entities of the public sector have to offer sustainable services from an economic, social and environmental perspective. Communicating how they achieve this, and to what extent they can continue to do so in the future, is fundamental for effective accountability and transparency. In addition, one of the main challenges of integrated information is that it seeks to strengthen the relationships between managers and stakeholders, involving the latter in strategic management and in the process of creating value, which is especially relevant in the case of public entities, where the commitment and participation of citizens are fundamental to ensure the success of the management of public services. This approach allows managers to consider all the resources used in the organization for the provision of services and their interrelationships, addressing all social and environmental impacts, in addition to financial ones in strategic decisions.

The integrated report aims to explain how the organization creates value over time, so it can be a tool to introduce value-based management. The report should provide information about the organization's strategy and how it relates to its ability to create value over time.

The process of creating value has some peculiarities in the field of public administrations, due to the type of activity they develop. In management based on the creation of value, the important thing is how decisions generate value and benefit, both for the organization and for its stakeholders (Moore, 2000). One of the problems in the public sector is precisely that strategic management is not sufficiently developed (Kearns, 1994), so the presentation of integrated reports offers a tool that can improve the management of organizations.

According to Moore (1995), the creation of value in the public sector consists in meeting the needs and demands of citizens. This must be seen from two perspectives:

1) Citizens needs should be the basis for defining what the public administration should produce. When the public organization produces goods or services that have an impact to solve the identified public problems, they will create public value. In the author's opinion, it is directly related to the satisfaction of the users of the goods or services produced.

2) It is also important to consider how the services should be provided. That is, the organization must use public resources in the best possible way to satisfy the demands of citizens.

In sum, Moore (1995) proposes that public value is created when the needs of citizens are met and they are served efficiently. 
The development of an integrated reporting system must be accompanied by a management system that focuses on the mission of the organization (Kaplan, 2001, Ebrahim, 2003). This system allows the definition of strategies and actions. The strategic plan should be based on creating value for each stakeholder and increasing it during the process (Moore, 2000), which can help leaders to define the concept of strategic management in a more appropriate way (Kong, 2008). This also requires the definition of available resources or capitals that allow the mission to be fulfilled in accordance with the strategies defined.

Integrated information is still a novel concept, with excellent opportunities for the public sector, but little extended in practice. The IIRC has created a "Network of pioneers in the public sector", to which the World Bank, the United Nations Development Program, the City of London Corporation, the City of London, the Audit Office of Wales and the government departments of the United Kingdom have joined. However, there is not much information about these experiences.

It is in the field of public companies where it has had the greatest reception (Garde and López, 2016), and among the entities that have joined this new initiative are, for example, the New Zealand Post, the Italian company of the sector of the energy ENI or the Russian atomic energy company, Rosatom (Manes Rossi, 2017). Also in public universities there are already some examples of integrated information (Brusca et al., 2018). In the area of local entities, we have only found the integrated report of the cities of Warsaw, in Poland, Sasso Marconi in Italy, and Instanbul Distric of Kadköy in Turkey.

\section{The non-financial statement in public sector}

The adoption of Directive 2014/95 / EU of the European Parliament and of the Council, of 22 October 2014, amending Directive 2013/34 / EU as regards disclosure of non-financial and diversity information by certain large undertakings and groups, has been a challenge for member states. In Spain, the transposition of the directive was initiated through Royal Decree-Law 18/2017, of November 24, which modifies the Commercial Code, the revised text of the Capital Companies Law approved by the Real Legislative Decree 1/2010, of July 2, and Law 22/2015, of July 20, on Audit of Accounts, regarding non-financial information and diversity.

Subsequently, Law $11 / 2018$, of December 28, which modifies the Commercial Code, the above mentioned text of the Capital Companies Law modified by Royal Legislative Decree 1/2010, of July 2, and the Law of 2015 on Audit of Accounts, with respect to non-financial information and diversity, fully incorporates Directive 2014/95/EU of the European Parliament and of the Council into the Spanish legislation.

The Law requires certain companies, either because of their size or because they are entities of public interest, to prepare a non-financial information statement, in which the business model of the company must be described.

The non-financial information statement must also include the following information: I. Information on environmental issues, such as pollution, circular economy and waste prevention and management, sustainable use of resources, climate change, and measures taken to preserve or restore biodiversity, and impacts caused by activities or operations in protected areas.

II. Information on social and personnel issues, including information on employment, work organization, health and safety, social relations, training, universal accessibility for people with disabilities, and equality.

III. Information on respect for human rights.
IV. Information related to the fight against corruption and bribery: measures taken to prevent corruption and bribery and to combat money laundering, as well as information about contributions to foundations and non-profit entities.

V. Information about society, which includes the company's commitments to sustainable development, the inclusion of social issues, gender equality and environmental issues in the purchasing policy; consideration of social and environmental responsibility in their relations with suppliers and subcontractors; supervision systems and audits and their results.

In addition, the law requires that the information included in the non-financial statement be verified by an independent expert.

This non-financial statement opens a new era in the information of companies and their verification. And the question is whether it should also be extended to public administrations. These entities have no obligation to prepare a management report so, in principle, it might seem unnecessary to require this statement of non-financial information.

As has been argued in the paper, public administrations have an important role in the process of change towards sustainable development. And this implies that they must develop active policies, both internal and external, so that management be done according to the principles of sustainable development and promote environmental culture. Action in these areas requires the development, in parallel, of a sustainable development strategy by administrations and the implementation of adequate internal environmental management systems.

Therefore this new non-financial statement also has a place in the public sector and offers opportunities for administrations to be accountable from a global perspective, integrating social, environmental and economic sustainability. In the coming years, some administrations will develop initiatives in this regard, and they should be expanded and improved in all administrations, addressing the challenges proposed by the European Union. In fact, at the United Nations Conference on Environment and Development (UNCED), held at Rio de Janeiro in 1992, it was agreed that each State, each Region and each Local Entity would elaborate their own strategy of sustainable development, in the Local Agenda 21, whose objective is to promote sustainable development.

The integration of non-financial information in the annual report will allow integrating all the information in the same document, an objective pursued with integrated information, and offer opportunities for the public sector.

\section{Popular reporting and the citizens report}

In the United States and Canada, the concept of popular reporting, understood as information aimed at the citizen, has taken root and its presentation should be based on criteria that are a little different from the traditional financial report (Biondi and Bracci, 2018), which is too long and not very understandable for citizens who are not experts in accounting matters. This initiative emerged in the late 1990s in the United States (Carpenter and Sharp, 1992) and has been developed with the support of three organizations: the Governmental Accounting Standards Board (GASB), the Association of Governmental Accountants (AGA) and the Government Financial Officers Association (GFOA). In all cases, this information is complementary to the annual financial report.

These organizations have proposed different alternatives for the report, although all of them have a common objective of increasing the transparency and accountability of ad- 
ministrations, preparing a report that is understandable for citizens and allows accountability from different perspectives. The GFOA proposes a Popular Financial Report, the GASB the Service Efforts and Accomplishments Report and the AGA a report for the citizens that contains the most relevant information for them in a clear and easy to understand form. It should be noted, for example, that the AGA has established a prize for the best Efforts and Accomplishments Reports in the provision of services based on the criteria of the GASB.

Another type of reports prepared for citizens are the Service Charters (Gimeno, 2017), which are specific reports in which the entity informs citizens about the services it provides, the conditions in which they are dispensed, the commitments and quality standards that it assumes and the rights that assist them in relation to with these services. This type of report is being used in Spain by many public administrations and the main difference with popular reporting is that it is focus mainly on the services provided but does not evaluate the efficiency of the services.

The final objective of the popular information is to prepare a report that is brief but capable of clearly containing all the information that allows the citizen to understand and evaluate the management carried out by the administration. This information may be financial, managerial, social or environmental and can use more visual presentation formats such as tables, graphs, etc.

Although these reports are widespread in the United States (approximately 75\% of the local entities elaborate them periodically according to the work of Yusuf et al., 2013) and in Canada, it has had less diffusion in Europe, although there are more and more countries that choose to disclose information that is clear and understandable for citizens, accompanying the traditional financial report with some explanations and graphs that make the information understandable for non-accounting experts. However, there is still a long way to go and it will undoubtedly be a challenge for our administrations in the future, given that the methods of accountability used at present are hard for citizens to understand.

\section{Conclusions}

The transparency and accountability of administrations has become one of the objectives of the administrators and managers of public funds. This requires that economic, but also social and environmental information be provided and that it be comprehensible and clear to users. However, the preparation of sustainability reports is a practice that is not widespread in public administrations, despite all the benefits that have been claimed for it, both for companies and administrations.

In fact, there is a great awareness of the importance of reporting on social and environmental aspects by the administrations, and some of them already use the web to disclose them. For operational purposes, however, it may be considered more useful for this information to be presented jointly in a report, of which a good option is the integrated report.

Integrated reporting adopts a holistic and global information orientation, with the aim of overcoming the shortcomings of traditional models, focused on financial information, and the fragmentation of information into different types of reports, such as financial, social and environmental. But in addition to integrating all the relevant information in a single report, the integrated information aims to introduce a change in the organizational culture, so that the axis on which the company's strategy revolves is the process of creating value.
Among the changes sought with this new model are the use of strategic information (economic, social and environmental) in the daily decision making and the strengthening of the relationships with the different stakeholders.

Public administrations are responsible for the provision of public services to citizens, and have the obligation to provide them in an efficient and sustainable manner. This implies taking care of the resources available, not only the financial, but also the natural. The value creation process of a public administration has some characteristics of its own, but this does not prevent the application of the integrated reporting conceptual framework prepared by the IIRC, with possible any minimal adaptations derived from the specific characteristics of these entities.

Currently, integrated information is still voluntary for public administrative sector and there are few administrations that have taken any initiative, despite the recommendations of institutions such as the CIPFA and the Financial Directors Group of the British Universities.

Academics and researchers see in this new model a clear opportunity to improve the performance and accountability of public administrations. These circumstances make it possible to clarify that integrated information can be seen as a future challenge for public administrations, both nationally and internationally, with clear implications also in the area of audit of accounts and public performance.

Echoing the importance of these new approaches, the European Union has required the publication of non-financial information by large companies and public interest entities, which has generated various initiatives in member countries. In Spain, the non-financial statement is part of the annual, consolidated and individual, of the companies that exceed the limits set by the regulations. This non-financial report is perfectly applicable to public administrations and is very likely to be subject to regulatory development.

Another alternative that offers opportunities to improve the transparency and accountability of the administrations is the preparation of a report addressed to the citizens, in which financial, social and environmental aspects should be presented in a clear and understandable way. This is undoubtedly a path yet to be explored but one that can renew the relationship between the administration and citizens and increase their trust.

\section{Acknowledgements}

The authors gratefully acknowledge financial support from the Generalitat Valenciana AICO/2017/092

\section{Conflicts of interest}

The authors have no conflicts of interest to declare.

\section{References}

Abellan, M. D., Cueto, C., Gacía, J.J., Marín, J.L., Paredes, J.D., \& Rodríguez, E.M. (2017). Análisis del nivel de RSC de los ayuntamientos de la Región de Murcia: (1a fase) septiembre 2017. Cátedra de RSC de la Universidad de Murcia.

Adams, S., \& Simnett, R. (2011). Integrated Reporting: An opportunity for Australia's notforprofit sector. Australian Accounting Review, 21(3), pp. 292-301.

Biondi, L., \& Bracci, E. (2018). Sustainability, Popular and Integrated Reporting in the Public Sector: A Fad and Fashion 
Perspective. Sustainability, 10(9).

Brusca, M. I., \& Labrador M. (2017). El marco conceptual de la información integrada y su aplicación en el sector público. Revista Española de Control Externo, 19(57), 13-38.

Brusca, I., Labrador, M., \& Larran, M. (2018). The challenge of sustainability and integrated reporting at universities: a case study. Journal of Cleaner Production, 188, 347354.

Cohen, S., \& Karatzimas, S. (2015). Tracing the future of reporting in the public sector: introducing integrated popular reporting. International Journal of Public Sector Management, 28(6), 449-460.

Ebrahim, A. (2003). Accountability in Practice: Mechanisms for NGOs". World Development. 31 (5), 813-829.

Eccles, R. G., Krzus, M. P., \& and Watson, L. A. (2012). Integrated Reporting Requires Integrated Assurance. In Joe Oringel (Ed.), Effective Auditing for Corporates: Key Developments in Practice and Procedures (161-178). London: Bloomsbury Information Ltd.

Flores, F., Lizcano, J. L., Mora, M., \& Rejón, M. (2012). Información Integrada: propuesta de un modelo. Revista de AECA, 100, 32-36.

Garde, R., \& López, M. V. (2016). Aplicación del informe integrado en las empresas públicas. Auditoría pública: revista de los Órganos Autónomos de Control Externo, 68, 6982 .

Gimeno, A. (2017). Las cartas de servicio como instrumento para el desarrollo de la información integrada en las entidades públicas. Revista Española de Control Externo, 19(57), 129-169.

Global Reporting Initiative, GRI (2010). GRI Reporting in Government Agencies.

Global Reporting Initiative, GRI (2013). G4 Sustainability Reporting Guidelines: Reporting Principles and Standards Disclosures.

Global Reporting Initiative, GRI (2019). GRI database.

Governmental Accounting Standards Board, GASB (1994). Concepts Statement nž 2 "Service Efforts and Accomplishments Reporting". GASB.

International Integrated Reporting Council, IIRC (2013), The International Framework. http://www.theiirc.org/ (accessed 12 December 2018).

International Integrated Reporting Council (IIRC) and Chartered Institute of Public Finance and Accountancy (2016). Integrated thinking and reporting. Focusing on value creation in the public sector. An introduction for leaders. CIPFA.

International Public Sector Accounting Standards Board, IPSASB (2014). Conceptual Framework for General Purpose Financial Reporting by Public Sector Entities. IPSASB.

International Public Sector Accounting Standards Board, IPSASB (2015). Recommended Practice Guideline 3 (RPG 3), Reporting Service Performance Information.

Kaplan, R. (2001). Strategic Performance Measurement and Management in Nonprofit Organizations. Nonprofit Management and Leadership, 11(3), 353-370.

Katsikas, E., Manes-Rossi, F., \& Orelli, R. (2016), Towards Integrated Reporting: Accounting Change in the Public Sector. Cham, Switzerland: Springer.

Kearns, K. P. (1994). The strategic management of accountability in nonprofit organizations: An analytical framework. Public Administration Review, 54, 185-192.

Kong, E. (2008). The development of strategic management in the nonprofit context: Intellectual capital in social service nonprofit organizations. International Journal of
Management Reviews, 10(3), 281-299.

Lev, B., \& Gu, F. (2016). The end of accounting and the path forward for investors and managers. Hoboken, New Jersey: John Wiley \& Sons.

Manes-Rossi, F. (2017). Experiencias de información integrada en entidades públicas en Europa. Revista Española de Control Externo, 19(57), 39-66.

Manes-Rossi, F. (2019) (in press). New development: Alternative reporting formats: a panacea for accountability dilemmas?. Public Money \& Management.

Moore, M. H. (1995). Creating Public Value. Strategic Management in Government. Cambridge: Harvard University Press.

Moore, M.H. (2000). Managing for value: organizational strategy in for-profit, non-profit, and governmental organizations. Non-profit and Voluntary Sector Quarterly, 29(1), 183204.

Navarro, A., Alcaraz, F. J., \& Ortiz, D. (2010). La divulgación de información sobre responsabilidad corporativa en administraciones públicas: Un estudio empírico en gobiernos locales. Revista de contabilidad, 13(2), 285-314.

Yusuf, J. E., Jordan, M. M., Neill, K. A., \& Hackbart, M. (2013). For the people: Popular financial reporting practices of local governments. Public Budgeting \& Finance, 33(1), 95-113. 